\title{
Depth-distribution of lake benthic diatom assemblages in relation to light availability and substrate: implications for paleolimnological studies
}

\author{
Andrea M. Hofmann (iD $\cdot$ Juergen Geist $\cdot$ Lena Nowotny $\cdot$ Uta Raeder
}

Received: 31 August 2018/Accepted: 17 June 2020/Published online: 25 June 2020

(C) The Author(s) 2020

\begin{abstract}
We analyzed the depth distributions of benthic diatoms in two adjacent, but hydrologically distinct subalpine lakes (Lakes Soiernseen, S-Germany). Lake Unterer Soiernsee is affected by marked water-level fluctuations and is light-penetrated to the bottom most of the year, while Lake Oberer Soiernsee provides more stable conditions and an extended aphotic zone. Mixed samples of epiphytic, epilithic, epipsammic and epipelic periphyton were taken in one-meter depth steps by scuba divers. Most of the common benthic diatoms occurred in distinct depthareas. RDA analyses showed that depth was strongly correlated with species distribution in both lakes. Depth-constrained cluster analyses indicated three
\end{abstract}

Electronic supplementary material The online version of this article (https://doi.org/10.1007/s10933-020-00139-9) contains supplementary material, which is available to authorized users.

A. M. Hofmann $(\bowtie) \cdot$ J. Geist · L. Nowotny · U. Raeder Aquatic Systems Biology Unit, Limnological Station Iffeldorf, Departement of Ecology and Ecosystem Management, Technical University of Munich, Hofmark 1-3, 82393 Iffeldorf, Germany

e-mail: a.hofmann@tum.de

J. Geist

e-mail: geist@wzw.tum.de

L. Nowotny

e-mail: nowotnylena@posteo.de

U. Raeder

e-mail: uta.raeder@tum.de distinct diatom community zones in each lake. A shallow littoral zone hosting mainly epiphytic and epilithic species and a deeper littoral zone with mainly epipsammic and epipelic taxa existed in both lakes. Additionally, a highly disturbed near-shore littoral zone with diatoms adapted to unstable conditions (aerophilic taxa, pioneer species) was found in Lake Unterer Soiernsee, and a deep-water pelagic zone with mainly planktonic taxa in Lake Oberer Soiernsee. Light availability, substrate, physical stressors and nutrient concentrations were linked closely with water depth. While light availability affected the ratio of benthic and planktonic diatoms, substrate type influenced benthic diatom assemblage structures. Diatoms occurring in surficial sediments of the aphotic zone represent an ideal cross-section of the recent diatom assemblage of the lake, including benthic and planktonic species. However, sediment samples taken in light-flooded depths are inappropriate for studies based on shifts between benthic and planktonic taxa, because in situ benthic species dominate the surfacesediment assemblages, while settled tychoplanktonic and planktonic species occur less frequently. A diatom-inferred depth model was created for each lake to prove the usability for down-core studies using weighted-averaging approaches. For both lakes these models are highly appropriate to reconstruct past fluctuations in water-transparency or lake-level. With regard to the development of diatom-based TP-transfer-functions for Bavarian mountain lakes, we found it 
is highly important to consider lake depth and transparency. Based on the findings of this study we recommend the creation of two different training-sets, one for deep or low-transparency lakes with an aphotic zone including both benthic and planktonic diatoms, and another one for shallow, clear water lakes solely using benthic diatoms.

Keywords Climate change - Subalpine lakes . Water-level fluctuations - Diatom community zones . TP-transfer function $\cdot \mathrm{B} / \mathrm{P}$ ratio

\section{Introduction}

Current global change is of multidimensional character (Catalan et al. 2013). Climate warming coupled with eutrophication is one of the most powerful drivers for the observed alarming alterations of aquatic ecosystems (Jacobson et al. 2017). Nutrient inputs into lakes, even into remote mountain lakes, have changed dramatically over many centuries due to human impacts such as deforestation, alpine pasture, fish stocking and mountain-hut-sewage (Kamenik et al. 2000) as well as changes in atmospheric deposition (Wolfe et al. 2001; Battarbee et al. 2010) and climate change (Dokulil 2013; Perga et al. 2015). Altered biogeochemical processes in the catchment triggered by regional climate warming may cause increased allochthonous nutrient loading, especially in combination with enhanced erosion as a result of increasing frequency and intensity of extreme rainfall events and storms (Dokulil 2013). Increasing air temperature may affect internal lake processes, mainly by enhanced algal productivity and altered thermal structure resulting in internal nutrient enrichment generated by nutrient release due to hypolimnetic oxygen stress (Anderson et al. 2012; Jeppesen et al. 2010). Direct impacts of climate warming, e.g. shortened ice cover duration, longer growing seasons, and increased water column stability, may alter the composition of primary producers. This is for instance evident from the increase of small-celled or colonyforming planktonic diatom taxa or rising benthic diatom assemblage complexity and species richness (Rühland et al. 2015). Due to their persistence, diversity and abundance in aquatic ecosystems, diatoms are widely used in paleolimnological studies.
Their resistant and species-specific siliceous valves are well preserved in lake sediments (Battarbee et al. 2001; Smol 2008). Many diatom taxa have welldefined habitat requirements and substrate preferences as well as distinct optima and tolerances relating to $\mathrm{pH}$-value, to salinity or to nutrient levels (Smol 2008; Battarbee et al. 2010) making them ideal indicators for the reconstruction of past environmental conditions. Diatoms respond rapidly to environmental and climate-driven changes in lake properties, thus they are highly suitable to reconstruct climate warming (Rühland et al. 2015) and lake eutrophication/recovery (Hall and Smol 1999). Past fluctuations of climate or trophic conditions are well preserved in lake sediment records (Smol 2008). Paleolimnological studies typically use shifts in ratios between planktonic and benthic diatom assemblages to reconstruct a series of climate-mediated water column properties, e.g. ice cover dynamic, mixing regime (Rühland and Smol 2005) and extension of the euphotic zone, as function of water level (Leira et al. 2015) or water transparency/nutrient status (Sayer and Roberts 2001; Laird et al. 2010; Althouse et al. 2014). In order to facilitate the reliable application of diatom-based predictions with respect to climate warming, eutrophication or water-level alterations, accurate knowledge of species-level diatom distribution in relation to lake ecosystems dynamics (habitat stability, substrate heterogeneity, light and nutrient availability) is important.

Here we present data from high-resolution analyses of diatom depth-distribution patterns in two adjacent subalpine lakes characterized by similar catchment geology, climate conditions, conductivity, $\mathrm{pH}$ and $\mathrm{TP}$ concentrations, but significantly different hydrological features such as depth, mixis type, and water-level fluctuations.

Previous diatom depth-distribution studies are either less detailed regarding the spatial resolution (Stevenson and Stoermer 1981; Moos et al. 2005; Cantonati et al. 2009) or based on several lakes with a range of regional and local factors (Kingsbury et al. 2012). Comparable detailed studies (Laird et al. 2010; Kingsbury et al. 2012; Gushulak et al. 2017; Raposeiro et al. 2018) exclusively used samples from the sediment surface. All these studies did not consider either epilithic or epipsammic/epipelic diatoms. However, to reproduce depth-distribution patterns of lake diatom communities all substrates should be included. 
We chose our sampling strategy (mixed substrate, including dead and live frustules) with regard to the applicability to paleolimnological analyses of sedimentary records, as surficial sediments contain in situ diatom taxa, dead valves from adjacent substrates, and sedimented frustules.

The objectives of our study were (1) to characterize the spatial variations in diatom assemblage composition with respect to depth, (2) to consider if these variations are significant enough to develop a diatom-inferred depth model for the studied lakes to reconstruct waterlevel dynamics via diatom assemblages preserved in lake sediments, (3) to identify potential differences between the diatom assemblages of the two adjacent but hydrologically different lakes, and (4) to validate if the studied lakes are appropriate calibration lakes for a surface sediment training set, in order to develop diatom-based TP (total phosphorus) transfer function for alkaline mountain lakes of the northern Alps.

With respect to spatial variations, we hypothesised (1) that the light availability controls the ratio between benthic and settled planktonic diatoms in surficial sediments and (2) that mainly the substrate influences the depth distribution of benthic diatoms. Additional hypotheses were that in case of prevailing aphotic conditions the diatom assemblages in surficial sediments of the deepest part of the basin are appropriate for diatom-based training sets to infer (3) past fluctuations of lake-levels and (4) trophic conditions.

Study site

Lakes Soiernseen (1552 $\mathrm{m}$ and $1558 \mathrm{~m}$ a.s.l.) are located in the Bavarian Alps $75 \mathrm{~km}$ south of Munich (Germany, Fig. 1) and are of glacial origin (März 1903). Originally, they formed a linked cirque lake until an end-moraine belt divided the upper lake from the lower lake (Schmidt-Thome 1953). Lithology and geological setting of the catchment area are dominated by Triassic dolomite and carbonate rocks (SchmidtThome 1953), which form the main karst aquifer. Quaternary glacial erosion caused the present shape of the caldron. Semipermeable moraine deposits seal the subsoil, forming the aquiclude (impermeable horizon) in the catchment area. Postglacial rock streams, talus slopes and alluvial cones have created another aquifer overlaying glacier deposits. Underground drainage dominates and underwater springs feed the lakes. Only Lake Unterer Soiernsee has a small surface inflow on the southwestern part of the lake. It constitutes the runoff from an artificial spring providing drinking water for two mountain huts. Lake Oberer Soiernsee drains through the permeable end moraine deposits into Lake Unterer Soiernsee (März 1903). Surface runoff from the upper to the lower lake occurs only after snowmelt, when water level is highest. Both lakes drain via groundwater into a small stream, springing up north of the cirque threshold. Anthropogenic pollution may occur from a small private mountain hut with a dry toilet, close to northern shore of Lake Oberer Soiernsee and from a nearby Alpine Association cottage, both highly frequented during summer months. The area surrounding the lakes is used for cattle grazing in July and August and the lakes are drinking water for the cattle. The high mountains (Schöttelkarspitze $2050 \mathrm{~m}$, Soiernspitze $2257 \mathrm{~m}$ and Gumpenkarspitze $2019 \mathrm{~m}$ ) forming the southern part of the surrounding caldron limit solar radiation during winter time (November-March).

\section{Materials and methods}

Sampling and data collection

The lakes were studied from August 2014 to November 2016. In August 2014, the morphology of the two lake basins was mapped with a sonar device (Biosonics Mx, Seattle USA). Temperature data loggers (Onset Hobo Pendant) were placed at depths of 0.2 , 3,5 and $8 \mathrm{~m}$ at a buoy positioned at the deepest areas of the lakes to record water temperature continuously from June 2015 to November 2016. A weather station (Davis Vantage Pro $2^{\mathrm{TM}}$ ) collected wind velocity and precipitation data from June to November 2016. Data from the weather station and the temperature loggers were used to gain information about energetic dynamics of the littoral zone and stratification patterns, which govern nutrient exchange between the epilimnion and the hypolimnion. The sampling frequency for physical parameters and phytoplankton analysis was monthly during ice-free periods (May-October 2015 and JuneNovember 2016). Physical parameters (temperature, conductivity, $\mathrm{pH}$, oxygen) were documented in onemeter depth increments using a multi-parameter probe (MPP 930 IDS WTW, Weilheim, Germany). Transparency was measured using a Secchi Disk. Mixed water samples for phytoplankton analysis were taken 


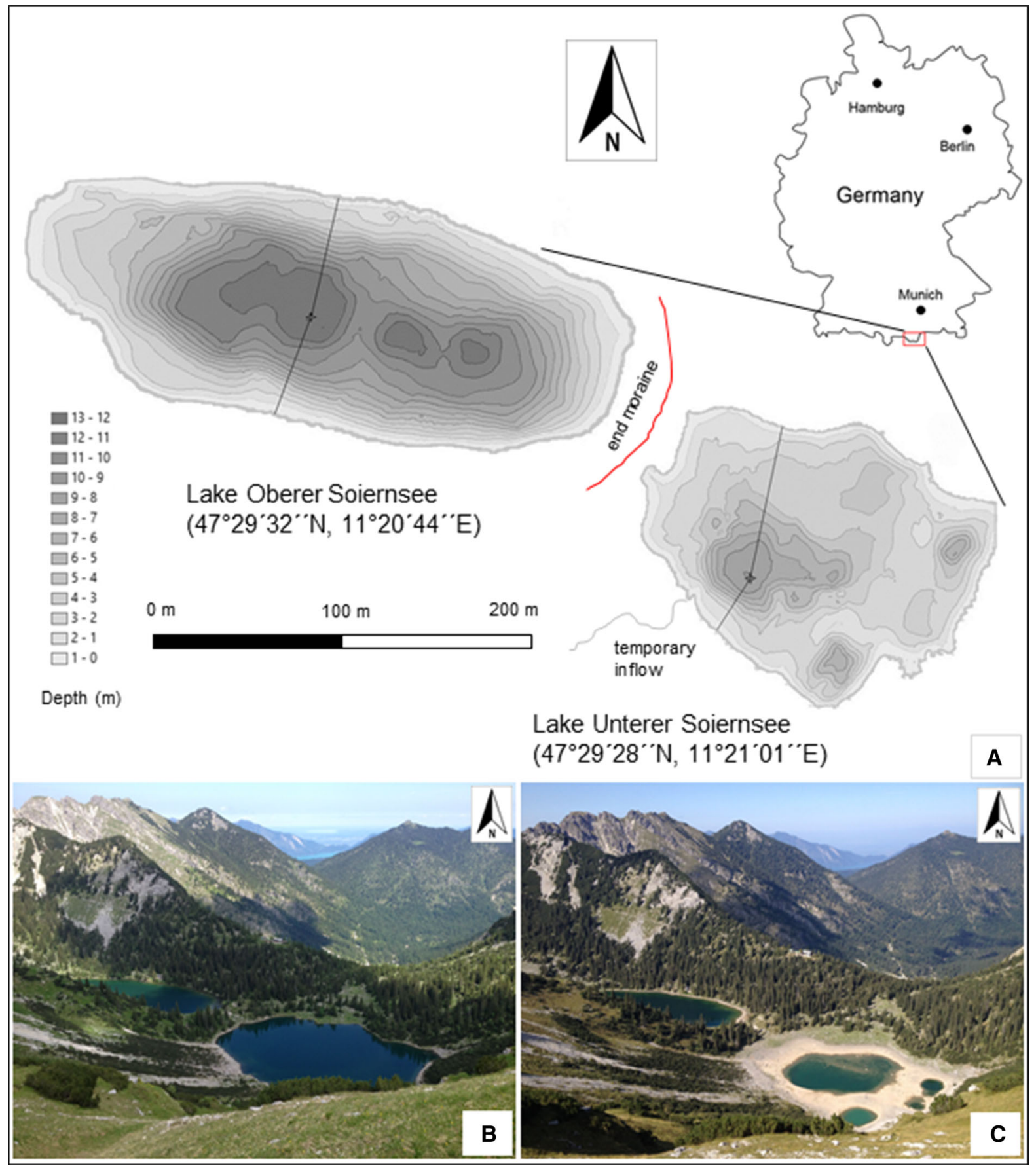

Fig. 1 Lakes Soiernseen: geographical location (a), bathymetric chart (a) including the course of the sampling transects. Photos taken in June (b) and October (c) show the extreme water level fluctuations of Lake Unterer Soiernsee

from the euphotic zone $\left(\mathrm{Z}_{\mathrm{eu}}\right)$, calculated on basis of Tilzer (1988)

$Z_{\text {eu }}=5 * \sqrt{\text { Secchi-Depth }}$ using a hose sampler (DIN EN 16698:2015-12). Water samples for hydrochemical characterization were taken monthly (May-October 2015) at 0.2, 2, 4, 6, 8, and $10 \mathrm{~m}$ depth as well as $0.5 \mathrm{~m}$ above the sediment 
(depending on seasonal water levels) using a Ruttner sampler. Concentrations of total phosphorus (DIN EN ISO 6878:2004-09), silica (Nanocolor silica test, Macherey-Nagel, Düren, Germany), nitrate-nitrogen (DIN 38405-9:2011-09) and ammonia-nitrogen (Navone 1964) were subsequently determined via spectrometric analyses (Hitachi, 150-20, Japan).

Diatom sampling for the depth profile took place in August 2016, at the same time as the macrophyte mapping of the lakes. Scuba divers recorded the structure of the lake bottom and the expansion of the different substrates (macrophytes, stones, sediment). They took the samples for diatom analyses in 0.3-0.5 $\mathrm{m}$ depths according to the European Water Framework Directive (Schaumburg et al. 2014) and in $1-\mathrm{m}$ depth increments along N-S transects encompassing differences in degree of slope, wind and wave exposure, and seasonal light conditions. The locations of the depth transects we used in this study are shown in Fig. 1. The scuba divers collected three fist-sized stones in closable, labeled polyethylene bags at each sample point. Additionally they carefully pulled off the uppermost sediment layer (sand, silt, clay) using labeled 60-ml syringes. Epilithon was removed from the stones using disposable toothbrushes. Epilithon and $20 \mathrm{ml}$ of sediment-water-suspension (epipsammon, epilpelon, epiphyton and sedimented planktonic organism) from each sampling depth were mixed together in 200-ml polyethylene bottles for subsequent analyses. The covering on the stones was documented descriptively and the estimation of the grain size was carried out by the finger test.

\section{Diatom analysis}

Mixed samples were prepared for diatom analysis using standard procedures: heating with $30 \%$ hydrogen peroxide for at least four hours to oxidize organic material, then adding concentrate hydrochloride acid to remove carbonates and finally rinsing the processed material with distilled $\mathrm{H}_{2} \mathrm{O}$ in four centrifugation steps (centrifugal acceleration $523 \mathrm{~g}$ ). Cleaned material was embedded in Naphrax (R.I. = 1.7) to get permanent slides. At least 550 pennate diatom valves per sample were identified under oil immersion at $1000 \times$ magnification using a Leiz Aristoplan microscope. Centric diatoms were summarized to "Centrales". Taxonomy followed Krammer and Lange-Bertalot (1986-1991), Lange-Bertalot (1993, 1996), Krammer (1997),
Lange-Bertalot and Krammer (2000-2003) and Hofmann et al. (2013), updated to recent taxonomic nomenclature using current publications about individual species and internet databases (Spaulding et al. 2018; Guiry and Guiry 2019). We used Trophic Index TI (Hofmann 1999) to evaluate trophic state of the lakes at the different depths along the two profiles. Planktonic diatoms were analyzed according to Utermöhl (DIN EN 15204:2006) using an inverted microscope (Leitz Labovert).

\section{Statistical analysis}

Only species with relative abundances greater than $1 \%$ in at least one sample were included in statistical analysis using PAST (version 3.18) statistical software package (Hammer and Harper 2006). Species abundances were Hellinger transformed (Legendre and Gallagher 2001) before analysis. Principal component analysis (PCA) was used for graphical illustration of diatom-community grouping in different depth zones and enables identification of the species most responsible for defining these zones. A prior DCA test (first DCA Axis $<3$ units of standard division) indicated that a linear PCA approach was appropriate for our study (Lepš and Šmilauer 2003). Depth-constrained cluster analysis (Euclidean hierarchal clustering in PAST) was used to define the different diatomassemblages-zones. A one-way analysis of similarity (ANOSIM, Clarke 1993) was run with 9999 permutations in PAST to verify the similarity of the defined community-zones. Species richness and diversity (Shannon-Index, evenness) were calculated in PAST (Bootstrap N 9999). RDA was run with 999 permutations using $\mathrm{R}$ (version 3.4.3) and the package vegan (Oksanen et al. 2018) to determine the variance in diatom communities that can be explained by depth. Quantitative depth models were developed using R (version 3.4.3) and the package rioja (Juggins 2018). For both lakes the strongest model based on a weighted-averaging partial-least-square approach (WA-PLS) with 2 components (Lake Oberer Soiernsee) and 3 components (Lake Unterer Soiernsee) were selected, respectively. RMSE results were calculated under cross validation with bootstrapping. 


\section{Results}

Bathymetry

Lake Unterer Soiernsee consists of one main basin (max. depth $15 \mathrm{~m}$ ) and three smaller basins on the eastern part of the lake (max. depths 8-12 m, Fig. 1a). During the study period (August 2014-November 2016), marked seasonal water-level fluctuations were observed $(9.5 \mathrm{~m})$. The elongated basin of Lake Oberer Soiernsee has a maximum depth of $14.5 \mathrm{~m}$ (Fig. 1a). Moraine material seals the lake's bottom; therefore the lake level fluctuations $(1.8 \mathrm{~m})$ are less than in Lake Unterer Soiernsee (Fig. 1b, c). Generally maximum lake levels occur after snowmelt followed by continuous decrease of the lake water level during summer and a minimum during winter drought. However, after longer rainy periods, short-term lake-level rises were observed. In August 2016, during diatom sampling, maximum depths of $8.5 \mathrm{~m}$ (Lake Unterer Soiernsee) and $13.5 \mathrm{~m}$ (Lake Oberer Soiernsee) were measured.

Weather station data

During the ice-free period (June-November), a rainfall sum of $1348 \mathrm{~mm}$ was measured. Four heavy rainfall events $\left(>20 \mathrm{~mm} \mathrm{~h}^{-1}\right.$ precipitation) were recorded: June $12(25.4 \mathrm{~mm})$, June $24(21.6 \mathrm{~mm})$, July 7 $(23.9 \mathrm{~mm})$ and August 18 (22.3 mm). The July event resulted in low water transparency during our sampling on August 2 (1.8 m Secchi depth). The predominant prevailing wind directions W (16\%), ESE (15\%), WSW (14\%) and E (13\%) and subsequent water action primarily affect the northern shores of both lakes.

Physical and chemical parameters

Average Secchi disk transparency was around $4 \mathrm{~m}$ in both lakes. Heavy rainfall events during the study period with massive surface runoff caused several short-term turbidities with Secchi depths lower than $1 \mathrm{~m}$ in both lakes. However, Lake Unterer Soiernsee was light-flooded to the bottom during most of the study period. In contrast Lake Oberer Soiernsee is characterized by light-limited conditions in the deepest part of the lake, as its euphotic zone comprised about $10 \mathrm{~m}$ of water column. Temperature logger data as well as monthly measuring during ice-free periods point out the polymictic character of Lake Unterer
Soiernsee, with a tendency towards short-term stratification during stable, warm periods. Due to polymixis no vertical gradients in chemical and physical parameters occurred. Only slight, seasonal variations in chemical and physical parameters were observed in Lake Unterer Soiernsee. In contrast, Lake Oberer Soiernsee showed longer periods of stable stratification. The $\mathrm{pH}$ values, as well as nitrate-nitrogenconcentrations, decreased slightly with increasing depth whereas total phosphorus concentrations increased marginally with depth during summer months. Conductivity, as well as ammonia-nitrogen and silica concentrations were directly proportional to depth. The mean total phosphorus concentrations suggested an oligo-mesotrophic character of both lakes. A massive thunderstorm in July 2015, with intense rainfall and mudflows caused extreme turbidity of the lakes for nearly six weeks, resulting in a significant increase of total phosphorus concentrations in both lakes (approx. $30 \mu \mathrm{g}^{-1}$ ). The karst catchment causes low conductivities in both lakes.

\section{Phytoplankton}

Phytoplankton biomass and species composition of the submerged vegetation indicate oligo- to mesotrophic conditions. In general, phytoplankton biomass was very low and consisted mainly of Dinophyceae and Diatomeae, dominated by the pennate, colony-forming Fragilaria nanana. Centric diatoms occur in very low proportions. Tychoplanktonic diatoms detached from their substrate reached abundances up to $35 \%$ (Lake Unterer Soiernsee) and 7\% (Lake Oberer Soiernsee) of the bulk plankton biomass.

Substrate for benthic diatoms

The macroalga Chara contraria A. Braun ex Kützing dominated the submerged vegetation of both lakes. At the date of macrophyte mapping, C. contraria formed continuous meadows in the three smaller basins of Lake Unterer Soiernsee and occurred in patches of different sizes in its main basin (1-3 m). In Lake Oberer Soiernsee, light mixed stands of $C$. contraria and $C$. tomentosa $\mathrm{L}$. occurred up to $6 \mathrm{~m}$ depths. Ranunculus trychophyllus Chaix ex Villard appeared along the entire shoreline of Lake Oberer Soiernsee but only in scattered patches in the northern part of Lake Unterer Soiernsee. Potamogeton alpinus Balb. 
was found in small patches at $0.5-1.5 \mathrm{~m}$ depths only in Lake Oberer Soiernsee.

Stones dominated as substrate in Lake Unterer Soiernsee, but with increasing depths they were more and more covered by sediment. At the deepest point of the lake stones lacked and exclusively fine sediment occurred. At the deepest area of Lake Oberer Soiernsee the sediment was rather solid covered only by a thin, loose layer. With decreasing depths the sediment became more and more loose (billowing). In depths greater than 7-8 m mainly sediment was availably as substrate for benthic diatoms and even the stones were covered by sediment. Between 7 and $3 \mathrm{~m}$ stones, at the southern slope even boulders dominated and sites with fine sediment were rare. Near the shore (0-3 m) stones and sediment were evenly distributed and the sediment was no longer billowing, but soft, with a flaky, loose coating. The finger test supported the divers' observations that the sediment became denser and therefore finer with increasing depths.

\section{Diatoms}

A total of 229 pennate diatom taxa belonging to 51 genera were found in 46 samples taken from Lakes Soiernseen. The 31 most frequent taxa (contributing $>1 \%$ of the diatom community) are listed in Table 1 . Additionally five centric species could be identified in both lakes. Hierarchal clustering and PCA allowed the definition of different depth correlated communityzones with characteristic diatom species (Figs. 2, 3). Three benthic zones were identified in Lake Unterer Soiernsee, two benthic zones and a planktonic zone in Lake Oberer Soiernsee. One-way ANOSIM tests running with 9999 permutations point out the significant differences between the community-zones.

\section{Diatom assemblage zones}

Results from the RDA showed that depth strongly correlated with diatom species distribution. RDA Axis 1 highly significantly $(p<0.001)$ explained $23 \%$ (Lake Unterer Soiernsee) and 35\% (Lake Oberer Soiernsee) of the variance according to the Monte Carlo Permutations Test. The developed WA-PLS models provide a robust reconstructive relationship between diatom-distribution and lake depth: $\mathrm{r}^{2}=0.95$; RMSEP $=0.59 \mathrm{~m}$ (Lake Unterer Soiernsee) and $r^{2}=0.56$; RMSEP $=2.55 \mathrm{~m}$ (Lake Oberer
Soiernsee). The PCA scatterplots indicate discrete diatom communities along the depth gradients in both lakes and detect the taxa relevant for these arrangements. In Lake Unterer Soiernsee, separation of the diatom assemblages from the depths $0-4 \mathrm{~m}\left(\mathrm{LS}_{1}\right)$ and the depths 5-8 $\mathrm{m}\left(\mathrm{LS}_{2}\right)$ is clearly visible (Fig. 4a). However, the separation of the $8.5 \mathrm{~m}$-depth triggered by dominance of Sellaphora mutata (Krasske) Lange Bertalot is less obvious. The remarkable outside position of $0 \mathrm{~m} \_\mathrm{S}$ is caused by dominance of $\mathrm{Di}$ adesmis contenta (Grunow) DG Mann. The scatterplot of Lake Oberer Soiernsee (Fig. 4b) shows the clusters of the deepest samples (P: 12-13.5 m) differing from those of mid depth group (LD: 7-11 m) and the shallow water samples (LS: 0-6 m). The extraordinary position of the deep-water sample $11 \mathrm{~m} \_\mathrm{N}$ within the near shore samples lead to the assumption that we sampled erratic stones at this depth (Fig. 4b).

\section{Depth-distribution of the diatoms in Lake Unterer Soiernsee}

In Lake Unterer Soiernsee, 19 samples were taken and a total of 169 pennate diatom species representing 46 genera were identified, 21 of them occurred in abundances $>1 \%$ (Table 1). Pennate diatoms dominated the diatom assemblages by far. Centrales were only found sporadically $(0.4 \%)$ and were mainly represented by Cyclotella praetermissa Lund and Cyclotella comensis Grunow. Encyonopsis subminuta Krammer and Reichardt (12\%), Achnanthidium minutissimum var. minutissimum (Kützing) Czarnecki (11\%), Denticula tenuis Kützing (9\%), Brachysira neoexilis Lange-Bertalot (7\%), and Achnanthidium sp. (5\%) were the most frequent diatoms. Depth-constrained cluster analysis and PCA separate three benthic community-zones, a near-shore littoral zone $\left(\mathrm{LS}_{1}\right)$, a shallow littoral zone $\left(\mathrm{LS}_{2}\right)$, and a deeper littoral zone (LD) (Figs. 2, 4a).

With increasing depth, abundances of certain taxa changed gradually and there were differences between the gentle northern slope and the steeper southern slope. There was no clear, sharp boundary identified between the three zones, rather areas of higher abundances of certain taxa, gradually changing with depth. Diadesmis contenta only occurred in the nearshore samples of the southern transect (57\%), Simonsenia delognei (Grunow) Lange-Bertalot dominated the southern transect at a depth of $6 \mathrm{~m} \mathrm{(14 \% ).}$ 
Table 1 Most frequent pennate diatom taxa $(>1 \%)$ of both lakes, their abbreviations, trophic and moisture preferences

\begin{tabular}{|c|c|c|c|c|c|}
\hline Taxa & Acronym & $\mathrm{T}$ & G & VDT & VDM \\
\hline Achnanthes minutissimum var. "schmale Sippe" Krammer and Lange-Bertalot & Ach_sch & & & & \\
\hline Achnanthidium caledonicum Lange-Bertalot & A_cal & 1.8 & 3 & & \\
\hline Achnanthidium minutissimum var. jackii (Rabenhorst) Lange-Bertalot & A_jac & & & & \\
\hline Achnanthidium minutissimum var. minutissimum (Kützing) Czarnecky & A_min & & & 7 & 3 \\
\hline Achnanthidium sp. & A_sp. & & & 1 & \\
\hline Achnanthidium straubianum Lange-Bertalot & A_str & & & & \\
\hline Adlafia bryophila (Petersen) Lange-Bertalot & Adl_bry & & & 3 & 5 \\
\hline Amphora pediculus (Kützing) Grunow & Amph_ped & & & 5 & 3 \\
\hline Brachysira neoexilis Lange-Bertalot & Bra_neo & 1.9 & 2 & & \\
\hline Delicata delicatula (Kützing) Krammer & Del_del & 1.5 & 3 & 1 & 3 \\
\hline Denticula tenuis Kützing & Det_ten & 3 & 1 & 3 & 3 \\
\hline Diadesmis contenta (Grunow) DG Mann & Dia_con & & & & \\
\hline Encyonema minutum (Hilse) DG Mann & Enc_min & 2 & 2 & & \\
\hline Encyonopsis cesatii (Rabenhorst) Krammer & Encyo_ces & 1.5 & 3 & 1 & 3 \\
\hline Encyonopsis krammeri Reichardt & Encyo_kra & & & & \\
\hline Encyonopsis microcephala (Grunow) Krammer & Encyo_mic & & & 4 & 3 \\
\hline Encyonopsis minuta Krammer and Reichardt & Encyo_min & & & & \\
\hline Encyonopsis subminuta Krammer and Reichardt & Encyo_sub & & & & \\
\hline Fragilaria nanana Lange-Bertalot & Frag_nan & 2.1 & 1 & 2 & 2 \\
\hline Hippodonta neglecta (Lange-Bertalot) Metzeltin and Witkowski & Hip_neg & & & & \\
\hline Navicula cryptotenella Lange-Bertalot & Nav_cry & & & 7 & 2 \\
\hline Nitzschia dealpina Lange-Bertalot and G Hofmann & Nit_dea & 2.5 & 1 & & \\
\hline Nitzschia dissipata var. media (Hantzsch) Grunow & Nit_med & & & & \\
\hline Nitzschia fonticola Grunow & Nit_fon & 4.5 & 3 & 4 & 1 \\
\hline Nitzschia lacuum Lange-Bertalot & Nit_lac & & & 3 & \\
\hline Platessa conspicua (A Mayer) Lange-Bertalot & Plat_con & & & 7 & 1 \\
\hline Pseudostaurosira robusta (Fusey) Williams and Round & Pseu_rob & 2.5 & 1 & & \\
\hline Sellaphora mutata (Krasske) Lange-Bertalot & Sel_mut & & & 2 & 2 \\
\hline Simonsenia delognei (Grunow) Lange-Bertalot & Sim_del & 4.5 & 3 & 4 & 4 \\
\hline Staurosira venter (Ehrenberg) Hamilton & Stau_ven & & & 4 & 1 \\
\hline Staurosirella pinnata (Ehrenberg) Williams and Round & Stau_pin & & & 7 & 3 \\
\hline
\end{tabular}

T (trophic preferences, Hofmann 1999): 1.0-1.8: oligotraphent; 1.9-3.0: oligo- to mesotraphent; 3.1-4.4: meso- to eutraphent; 4.5-5.0: eutraphent

G (sensitivity value, Hofmann 1999): 1-3

VDT (trophic preferences, van Dam et al. 1994): 1: oligotraphent; 2: oligo- to mesotraphent; 3: mesotraphent; 4: meso-eutraphent: 5: eutraphent; 7: oligo- to eutraphent

VDM (moisture preferences, van Dam et al. 1994): 1: almost never occurring outside water bodies; 2: mainly occurring in water bodies; 3: mainly occurring in water bodies and regularly in wet places; 4: mainly occurring in wet places; 5: nearly exclusively occurring outside water bodies

Denticula tenuis reached highest abundances between 3-6 $\mathrm{m}$ along the northern transect $\left(\mathrm{LS}_{1}, \mathrm{LS}_{2}\right)$, but it was most abundant between 2-4 $\mathrm{m}$ along the southern transect $\left(\mathrm{LS}_{1}\right)$. The following dominant species preferred distinct depths: Achnanthes minutissimum var. "schmale Sippe" Krammer and Lange-Bertalot, Achnanthidium caledonicum Lange-Bertalot, Brachysira neoexilis, and Encyonopsis subminuta were most 
Fig. 2 Depth-distribution and relative abundances of the most common $(>1 \%)$ benthic and of total centric diatom taxa in Lake Unterer Soiernsee with depth constrained cluster analysis. Diatom community-zones: $\mathrm{LS}_{1}$ (near-shore littoral zone), $\mathrm{LS}_{2}$ (shallow littoral zone), LD (deeper littoral zone). The expansions of the zones are illustrated by different shades of grey

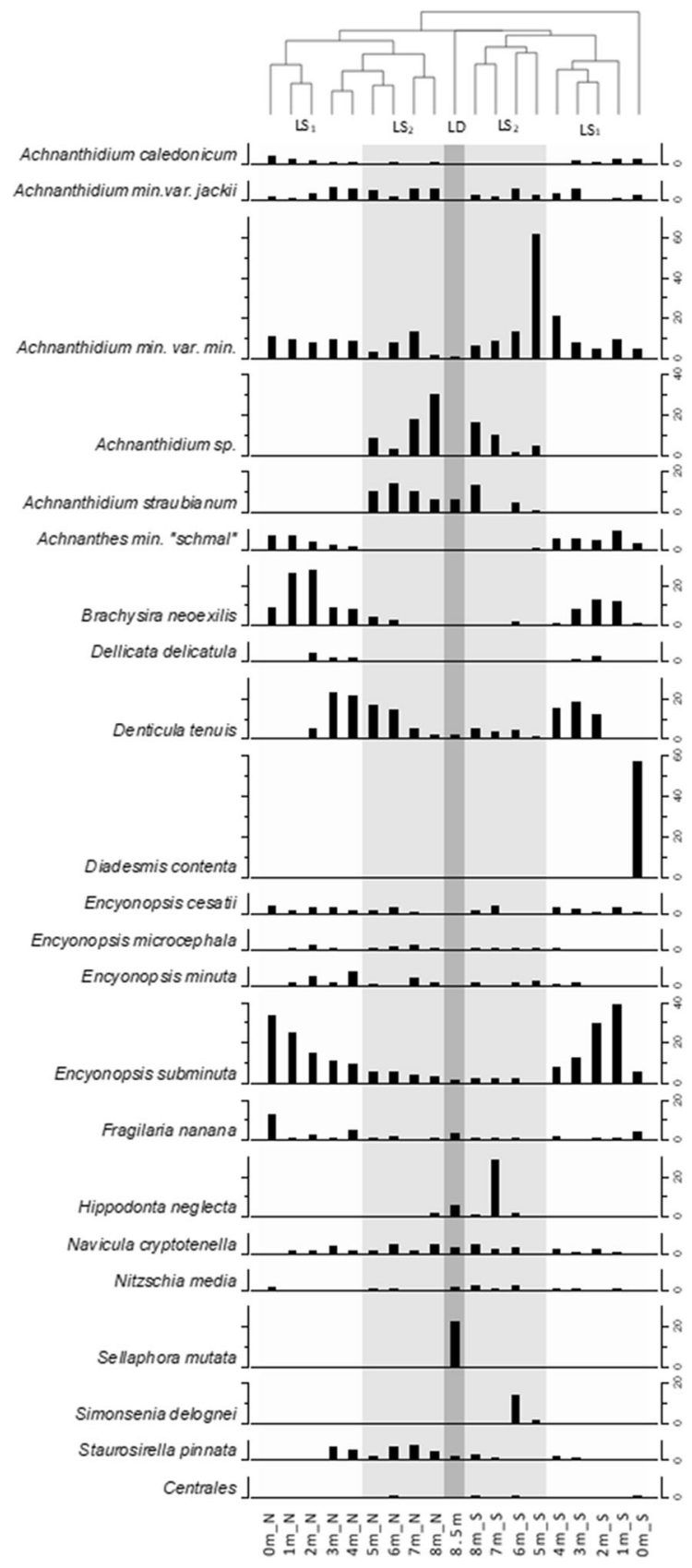

Cleve, Amphora pediculus (Kützing) Grunow, Gyrosigma acuminatum (Kützing) Rabenhorst and Fallacia lenzii (Hustedt) Lange Bertalot) also showed marked preferences for $\mathrm{LS}_{2}$. Some of the most common species (A. minutissimun var. minutissimum, A. minutissimum var. jackii (Rabenhorst) Lange-Bertalot, Fragilaria nanana Lange-Bertalot and Navicula cryptotenella Lange-Bertalot), however, were found 
Fig. 3 Depth-distribution and relative abundances of the most common $(>1 \%)$ benthic and of total centric diatom taxa in Lake Oberer Soiernsee with depth constrained cluster analysis. Diatom community-zones: LS (shallow littoral zone), LD (deeper littoral zone), $\mathrm{P}$ (deep water planktonic zone). The expansions of the zones are illustrated by different shades of grey

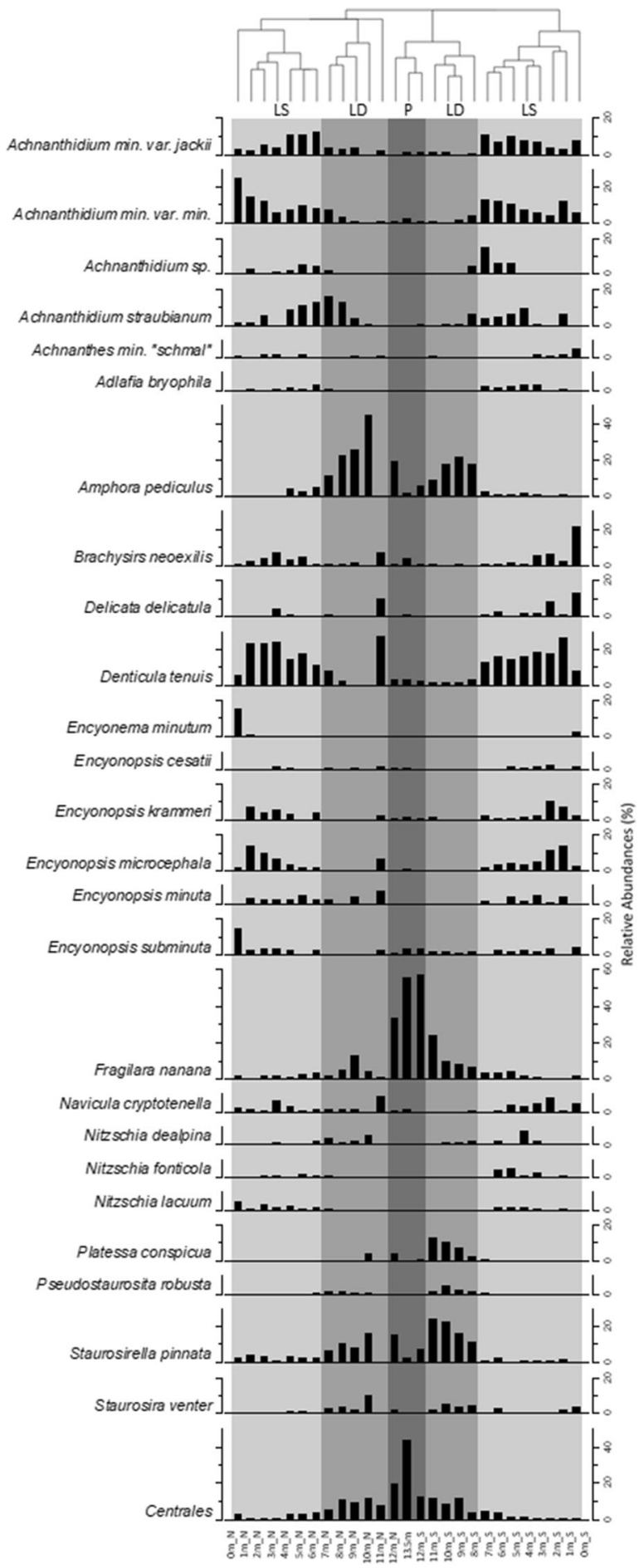

littoral community-zones $\mathrm{LS}_{1}$ and $\mathrm{LS}_{2}$ differ significantly, while the deeper littoral $\mathrm{LD}$ and $\mathrm{LS}_{2}$ communities show clear similarities. 

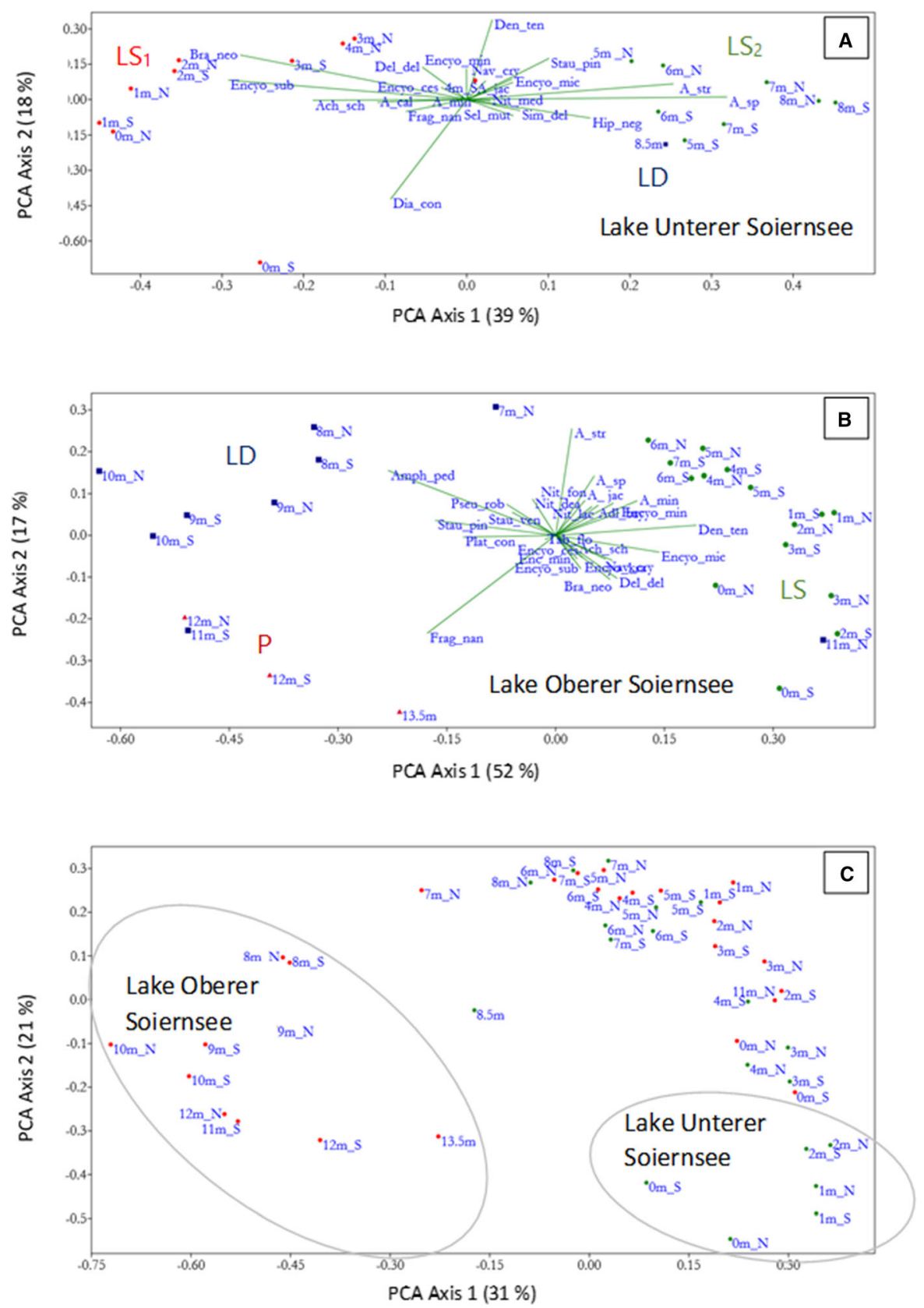

Fig. 4 Scatterplot of principal component analysis (PCA) showing the depth-distribution of the diatom communities and the dominant taxa in Lake Unterer Soiernsee (a) and Lake Oberer Soiernsee (b) from the northern $(\mathrm{N})$ to the southern (S) near-shore samples ( $0 \mathrm{~m} \_\mathrm{N}$ and $\left.0 \mathrm{~m} \_\mathrm{S}\right)$ to the deepest samples $8.5 \mathrm{~m}$ (Lake Unter Soiernsee) and $13.5 \mathrm{~m}$ (Lake Oberer Soiernsee). $\mathrm{LS}_{1}=$ near shore littoral zone (red dots), $\mathrm{LS}_{2}$ and $\mathrm{LS}=$ shallow littoral (green dots), LD = deeper littoral zone (blue squares), $\mathrm{P}=$ pelagial zone (wine-red triangles). Acronyms see taxa list. c Principal component analyses (PCA) comparing the diatom communities of both lakes. Differences are clearly visible by special position of the near-shore samples of Lake Unterer Soiernsee (green dots) and the deeper-water samples of Lake Oberer Soiernsee (red dots). (Color figure online) 
Depth-distribution of the diatoms in Lake Oberer

Soiernsee

A total of 172 pennate diatom taxa representing 37 genera were identified in the 27 samples taken from Lake Oberer Soiernsee; 25 of them occurred in abundances $>1 \% \quad$ (Table 1). Centric diatoms occurred in abundances between $0.6 \%\left(1 \mathrm{~m} \_\mathrm{N}\right)$ and $44 \%$ (deepest area) and were mainly represented by Cyclotella comensis and Cyclotella woltereckii Hustedt, subordinated by Cyclotella costei Druart and Straub, Cyclotella ocellata Pantocsek and Cyclotella praetermissa. Denticula tenuis (12\%), Fragilaria nanana (10\%), Amphora pediculus (8\%), Achnanthidium minutissimum var. minutissimum (7\%), Staurosirella pinnata (7\%), Achnanthidium minutissimum var. jackii (5\%), and Achnanthidium straubianum (5\%) were common taxa in this lake (Fig. 3). Depthconstrained cluster analysis and PCA suggest there were three community zones (Figs. 3, 4b): two benthic zones (LS and LD) and a deep-water planktonic zone (P). Note that the LD zone differs between the two slopes.

Similar to Lake Unterer Soiernsee, the most frequent taxa showed clear depth-distribution patterns, but species changed gradually, especially across the two benthic zones. High abundances of planktonic diatoms, suggest a sharp boundary occurred between the benthic zones and the planktonic zone. Achnanthes minutissima var. "schmale Sippe", Achnanthidium sp., A. minutissimum var. minutissimum, A. minutissimum var. jackii, A. straubianum, Adlafia bryophila (Petersen) Lange-Bertalot, Brachysira neoexilis, Delicata delicatula (Kützing) Krammer, Denticula tenuis, Encyonopsis cesatii (Rabenhorst) Krammer, E. krammeri Reichardt, E. microcephala (Grunow) Krammer, E. minuta Krammer and Reichardt, and E. subminuta appeared to prefer zone LS. Amphora pediculus, Platessa conspicua (A Mayer) Lange-Bertalot, Pseudostaurosira robusta (Fusey) Williams and Round, and Staurosirella pinnata favored the LD zone. The planktonic taxon Fragilaria nanana dominated the pennate diatom assemblages in $\mathrm{P}$, where the centric diatoms reached highest percentages (16-44\%). Encyonema minutum (Hilse) DG Mann was only dominant in the uppermost sample of the northern transect $\left(0 \mathrm{~m} \_\mathrm{N}\right)$. PCA and hierarchal clustering point out the extraordinary positioning of the $11 \mathrm{~m} \_\mathrm{N}$ sample with high abundances of typical LS epilithic taxa. It is possible that erratic stones from the shore were sampled. The ANOSIM test $(R=0.78$, $p=0.0001$ ) indicates that the three community zones are significantly different from each other.

Comparison of the diatom assemblages of the two lakes

The shallow-water diatom assemblages of Lake Unterer Soiernsee $(0-2 \mathrm{~m})$ differed clearly from all other assemblages (Fig. 4c). The near-shore assemblages $(0 \mathrm{~m})$ of Lake Oberer Soiernsee were similar to the assemblages found in 3-4 $\mathrm{m}$ in Lake Unterer Soiernsee. Only the assemblages of the deepest sample of Lake Unterer Soiernsee $(8.5 \mathrm{~m})$ showed similarity to the deeper-water assemblages of Lake Oberer Soiernsee $(8-13.5 \mathrm{~m})$. The diatom assemblages of both lakes were most similar at medium depths (5-7 m).

Species richness and diversity of pennate diatoms, trophic states and $\mathrm{B} / \mathrm{P}$ ratios

In both Lakes Soiernseen species richness and diversity indices were lowest in near-shore samples and highest in depths between 6 and $8.5 \mathrm{~m}$ (Fig. 5). In Lake Oberer Soiernsee indices increased from the near-shore to the mid-depths and declined clearly to the deep-water zone (Fig. 5b). Species richness per individual sample ranged from 33 to 74 taxa (Lake Unterer Soiernsee) and from 32 to 62 taxa (Lake Oberer Soiernsee). Diversity was calculated as Shannon Index (Lake Unterer Soiernsee 1.83-3.42, Lake Oberer Soiernsee 1.95-3.27) and as evenness (Lake Unterer Soiernsee 0.16-0.46, Lake Oberer Soiernsee $0.17-0.48)$.

In Lake Unterer Soiernsee the trophic state expressed by TI tends to rise with increasing depth (Fig. 5), reaching highest values in the deepest area (except TI of 5m_S and 6m_S). TI analyses indicate oligotrophic conditions occurred in the shallow littoral (0-2m_N, 0-1m_S) whereas oligo- to mesotrophic conditions occurred from 3 to $7 \mathrm{~m}$ at the northern littoral zone and from $2 \mathrm{~m}$ to $4 \mathrm{~m}$ plus $7 \mathrm{~m}$ at the southern slope. TI values of the deepest area $(8 \mathrm{~m}$, $8.5 \mathrm{~m}$ ) and of $5 \mathrm{~m} \_\mathrm{S}$ signify mesotrophic conditions, TI analyses of 6m_S indicated meso- to eutrophic conditions. In Lake Oberer Soiernsee TI analyses indicated nearly constant oligo- to mesotrophic 
conditions occurred (Fig. 5). In the northern slope, TI values tend to be slightly higher characterizing mesotrophic states. At 8m_S, mesotrophic conditions prevail, whereas TI indicated oligotrophic state at Om_S.

$\mathrm{B} / \mathrm{P}$ ratios of the diatom assemblages occurring in Lake Unterer Soiernsee showed no tendencies, the values varied between $6.4\left(0 \mathrm{~m} \_\mathrm{S}\right)$ and $95.6\left(7 \mathrm{~m} \_\mathrm{S}\right)$ along the depth profile (Fig. 5). In Lake Oberer Soiernsee, however, the B/P ratios clearly declined
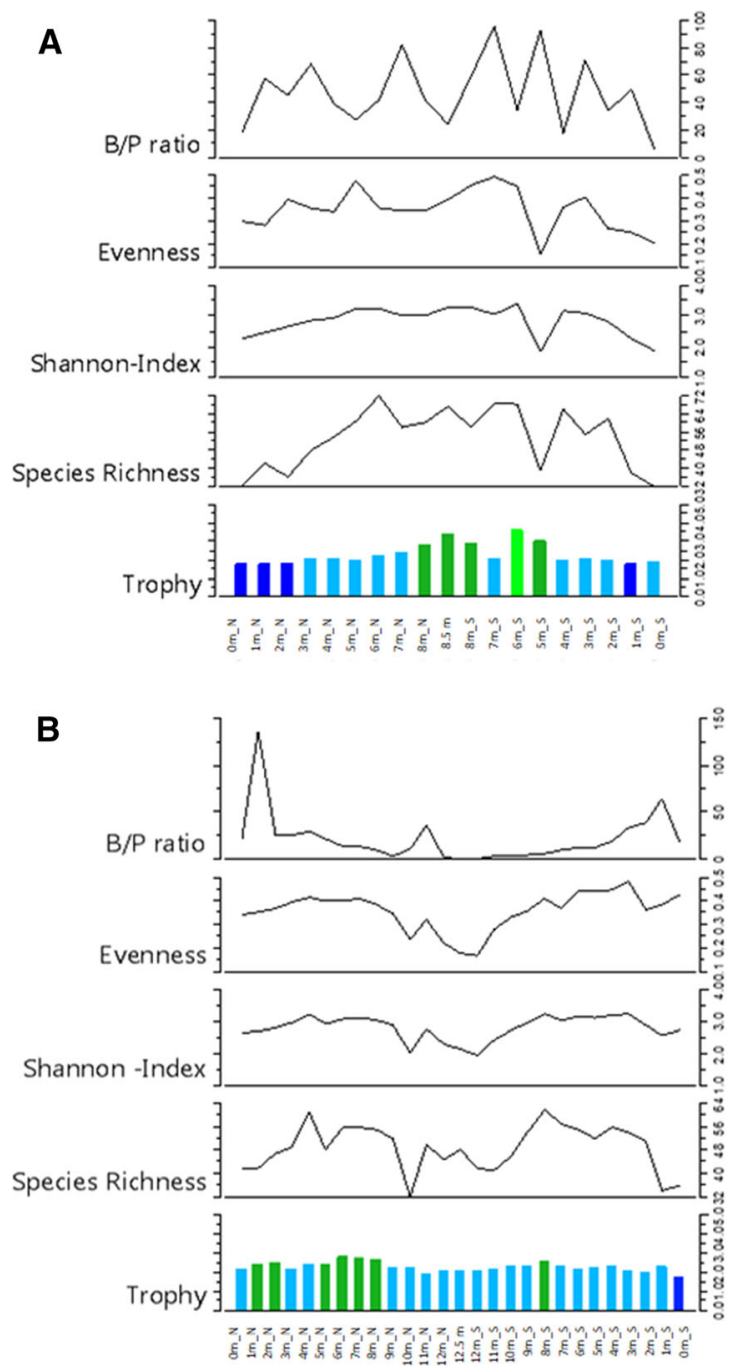

Fig. 5 B/P ratios (ratios between benthic and planktic diatoms), diversity indices (Species richness, Evenness, Shannon-Index) and Trophic Indices (TI) by Hofmann (1999) of Lake Unterer Soiernsee (a) and Lake Oberer Soiernsee (b). Dark blue $=$ oligotrophic, light blue $=$ oligo- to mesotrophic, dark green $=$ mesotrophic, light green $=$ mesotrophic-eutrophic conditions. (Color figure online) with increasing depths comprising values between 0.3 $(12.5 \mathrm{~m})$ and $134.8\left(1 \mathrm{~m} \_\mathrm{N}\right)$.

\section{Discussion}

Our findings indicate that depth significantly controls diatom species composition and dynamics in both Lakes Soiernseen. Three diatom assemblage zones along in-lake depth gradients could be identified: a near-shore littoral zone, a shallow littoral and a deeper littoral zone in Lake Unterer Soiernsee and a shallow littoral zone, a deeper littoral and a deep water planktonic zone in Lake Oberer Soiernsee. Comparable studies also indicate distinct depth-distribution patterns of benthic diatoms (Stevenson and Stoermer 1981; Moos et al. 2005; Cantonati et al. 2009; Laird et al. 2010; Kingsbury et al. 2012; Gushulak et al. 2017). Although we analysed diatom assemblages including live and dead frustules, the depth distribution of the in situ benthic diatom communities should be well represented, as in the photic zone the majority of diatom valves are living cells (Yang and Flower 2012). Especially in Lake Unterer Soiernsee the light flooded conditions resulted in dominant abundance of in situ taxa in the diatom assemblages, despite numerous planktonic and tychoplanktonic diatom species in the water column as a consequence of turbulent events and polymixis. Additionally diatom distribution-patterns were found to be highly similar in both transects of each study lake. Consequently, mass slides or redistribution of dead diatom valves seem to be irrelevant in Lakes Soiernseen.

Characterization of spatial variations within the diatom communities with respect to depth

We found that the following environmental factors are linked to water depth: light availability, substrate, disturbances (water-level fluctuations, wave action), and nutrient concentrations. All these factors influence the composition of the diatom assemblages.

As we hypothesised (1) light availability mainly controls the benthic/planktonic diatom ratio in surficial sediments. Indeed we found that in Lake Oberer Soiernsee an aphotic zone with lack of periphyic diatom growth exists (10-13.5 m) and the abundance of planktonic taxa significantly increase in samples 
taken deeper than $8 \mathrm{~m}$. In Lake Unterer Soiernsee however, euphotic conditions exist most of the year and benthic diatoms dominate diatom community on the lake bottom by far. The light attenuation depends on depth, phytoplankton biomass and the concentration of other light-absorbing particles or substances (Vadeboncoeur et al. 2014). In Lakes Soiernseen, light availability is primarily a function of depth. Additionally, precipitation-triggered catchment erosion and surface runoff may reduce the euphotic zone intermittently, but never phytoplankton shading. We found that epipsammic and epipelic diatoms were most abundant deeper than $7 \mathrm{~m}$, where temporarily light limited conditions were detected. These taxa are proved to have a variety of strategies to cope with light limitation or temporary darkness, e.g., forming resting cells (Hill 1996), switching to facultative heterotrophic metabolism (Lewin 1953; Tuchman et al. 2006; Cantonati et al. 2009; Kingsbury et al. 2012), motility (Moss 1977; Hill 1996), and increasing production of the light-capturing accessory pigment fucoxanthin (Cantonati et al. 2009).

As we hypothesized (2), substrate type influences the composition of benthic diatom assemblages. Comparable with Lowe (1996) we found that benthic diatom assemblages changed along a littoral depth gradient from shallow littoral epilithic and epiphytic rheobionts, which are adapted to water movements, to deeper littoral epipsammic and epipelic limnobionts, which benefit from stable and undisturbed environment. Epilithic (Denticula tenuis, Encyonopsis microcephala, E. minuta, E. subminuta) and epiphytic (Achnanthes minutissimum var. "schmale Sippe", Achnanthidium caledonicum, Brachysira neoexilis, Encyonopsis cesatii, E. krammeri, Encyonema minutum, Delicata delicatula) diatoms dominate the upper benthic zones. Epipsammic and epipelic taxa are significantly more frequent in the deeper benthic zones. The epipsammic diatom community represents a unique assemblage of small species (Staurosirella pinnata, Staurosira venter (Ehrenberg) Hamilton, Pseudostaurosira robusta, Platessa conspicua) firmly attached on single sand grains, resistant to abrasion and physical damage by moving sand particles and even tolerating short terms of darkness and brief anaerobic conditions (Moss 1977). The epipelic assemblages on fine sediments like clay or silt rely on motility to avoid permanent burial (Moss 1977; Burkholder 1996). We found that highly (Gyrosigma acuminatum), moderately (Navicula antonii LangeBertalot, Sellaphora pupula (Kützing) Mereschkowsky, Sellaphora mutata) or slightly (Amphora pediculus, Amphora ovalis Kützing, Diploneis oculata (Brébisson) Cleve, Platessa cospicua) motile epipelic species (Krammer and Lange-Bertalot 1986-1991) are more frequently deeper than 5-7 $\mathrm{m}$. The depth distribution patterns of small-celled stalked or slowly motile epiphytic diatoms, like Brachysira neoexilis and Encyonopsis cesatii (Letáková et al. 2016), reflect the presence of the stonewort stands in the shallow littoral zone of both lakes. The cell-to-cell linked, tube-forming Encyonema minutum, however, is associated with Potamogeton alpinus in Lake Oberer Soiernsee. Due to their harsh (carbonate encrusted) surface microstructure, Characeae represent a less appropriate substrate for high profile species (tall, tube-forming, chain-forming, filamentous or stalked diatoms), but small, adnate, short stalked or slow moving diatoms are quite common (Messyasz and Kuczynska-Kippen 2006). Despite our mixed sampling strategy we found a clear effect of substrate on the composition of diatom communities. Sampled substratum changed with depth, because grain size is generally proportional to the degree of physical disturbance (Forehead and Thompson 2010) and decreases naturally with distance from the shore (Hofmann et al. 2008; Yang and Flower 2012). Consequently, mud dominates the deeper parts of the lakes, while hard substrate is more frequent in the physically stressed upper littoral. We found stones throughout the depth profiles (with exception of the deepest area of Lake Unterer Soiernsee), but they were covered with sediment at greater depths. Consequently, real epilithic assemblages were unlikely in samples deeper than $6 \mathrm{~m}$. The significant decrease of the epilithic diatom Denticula tenuis in depths greater than 5-6 m supports this hypothesis.

Physical stressors such as water-level fluctuations and wave action also effect the distribution of benthic diatoms (Passy 2007; Cantonati et al. 2009). We found high abundances of pioneer species in the physically disturbed shallow littoral of both lakes. The appearance of aerophilic taxa and the lack of macrophytes as substrate for epiphytic taxa can be correlated with the enormous water-level fluctuations observed in Lake Unterer Soiernsee. Large scale water-level alterations with significant shore line displacement impact lake ecosystems by changing light regime, habitat 
availability, plankton dynamics, nutrient concentration and especially the development of the near-shore littoral zone, e.g. sediment resuspension, desiccation, freezing (Hofmann et al. 2008; Cantonati and Lowe 2014). Extreme water-level fluctuations also lead to an extirpation of vascular macrophytes (Rørslett 1991). Consequently exclusive Characeae are available host plants in habitats with significant fluctuations in hydrostatic pressure (Becker et al. 2016). We found a selection of diatom species in the highly disturbed near-shore zone of Lake Unterer Soiernsee adapted to drying out or changing moisture conditions, including Diadesmis contenta, Luticola mutica (Kützing) DG Mann, L. pseudonivalis (Bock) Levkov, L. saxophila (Bock ex Hustedt) DG Mann (van Dam et al. 1994; Poulíčková and Hašler 2007) and Encyonopsis subminuta (Novais et al. 2014).

Besides water-level fluctuations, short-term disturbances as wind and wave action impose physical stress on organisms living in the shallow littoral zone. The northern shores of both lakes are exposed to enhanced hydrodynamic energy due to the predominantly prevailing wind directions (WSW/ESE/SW/SE). The notably higher abundances of Staurosirella pinnata with its thick, solidly silicified cell wall and short, flexible mucilaginous stalk at the northern profile of both lakes may demonstrate that the northern shore is more exposed to wind and wave disturbance than the southern shore. Diatom growth forms and life strategies show adaptions to this highly dynamic habitat: strongly attached low-profile (prostrate, adnate, erect) taxa and r-selected taxa, e.g. small Achnanthidium and Achnanthes (Passy 2007; Kingsbury et al. 2012) are most abundant in the shallow littoral zones of both Lakes Soiernseen.

Nutrient availability was also found to influence the diatom distribution in both Lakes Soiernseen. Limiting nutrients for diatom growth are phosphorus and silica, as phosphorus is the main variable controlling diatom productivity and species composition (Battarbee et al. 2001) and silica regulates diatom metabolism and cell growth (Round et al. 1990). Concentrations of both nutrients vary with depth, especially in periodically stratified Lake Oberer Soiernsee. Dissolution, cell lysis and microbial degradation lead to enriched concentrations in deeper areas, while intensive biological consumption reduces nutrient availability in the shallow littoral (Wetzel 2001; Cantonati et al. 2009). High abundances of strongly silicified
Hippodonta neglecta in the deeper part of Lake Unterer Soiernsee and the occurrence of large species with heavily silicified frustules (e.g. Diploneis species) in the deeper benthic zone of both lakes indicate higher silica concentration by dissolution of sedimented diatom frustules (Cantonati et al. 2009). We also found that several epipelic diatoms, which are adapted to slightly higher phosphorus nutrient concentration reach highest percentages in the deeper littoral zones of both lakes: Amphora pediculus and Platessa conspicua (Kingsbury et al. 2012; Kitner and Poulíčková 2003; van Dam et al. 1994) or subdominant Gyrosigma acuminatum, Navicula antonii, $N$. associata Lange-Bertalot, $N$. hofmanniae Lange-Bertalot, N. trophicatrix Lange-Bertalot, and N. utermoehlii Hustedt (Schaumburg et al. 2014; Hofmann et al. 2013). Sediment dwelling taxa intercept dissolved nutrients from sediment and its interstitial water (Burkholder 1996; Poulícková et al. 2008), particularly because microbial degradation of detrital organic matter mainly occurs in surficial sediments (Wetzel 2001; Dodds 2003).

Diversity and species richness

The littoral zone represents a hotspot of diatom productivity and biodiversity (Althouse et al. 2014). It comprises mesohabitats of high substrate diversity (boulders, stones, sand, silt, clay, submerged macrophytes and stoneworts) providing ideal conditions for highly diverse diatom communities. The upper littoral zone, however, is characterized by high-energy conditions, high UV irradiation, water-level fluctuations and seasonal shifts in temperature (Cantonati and Lowe 2014). This may account for the low diversity indices in the near-shore habitat of both lakes. Effects of wave disturbance, however, decrease rapidly with depth (Vadeboncoeur et al. 2014). At mid-depth (4$8 \mathrm{~m}$ ), high habitat stability and substrate heterogeneity provide favorable growth conditions resulting in the higher species richness, diversity and evenness, observed in both basins. The consequences of reduced substrate variability and light availability in the deeper benthic zone are decreasing species richness and diversity. This pattern has also been observed in other lakes (Cantonati et al. 2009; Laird et al. 2010; Kingsbury et al. 2012; Yang and Flower 2012). 
Basic differences between the diatom assemblages of the two lakes

Species richness and diversity of the diatom assemblages as well as most of the dominant taxa were quite similar in both lakes. However, some significant differences in diatom composition occurred, primarily caused by the dramatic water-level fluctuations in Lake Unterer Soiernsee and the greater maximum depth of Lake Oberer Soiernsee. Feret et al. (2017) also found that water-level fluctuations and lake depth are important factors to explain variances in diatom species compositions. The extreme water-level fluctuations result in a highly disturbed near-shore littoral zone $\left(\mathrm{LS}_{1}\right)$, habitat for several aerophilic and subaerial species, which only appear in Lake Unterer Soiernsee. The instable habitat additionally leads to exclusive growth of Characeae, while the more stable environment of Lake Oberer Soiernsee offers a variety of host plants for epiphytic diatoms. The greater depth of Lake Oberer Soiernsee results in an extended deeper littoral, which host a more diverse epipelic community and in an aphotic, pelagic zone $(\mathrm{P})$. We found that benthic diatom assemblages occur throughout the basin of Lake Unterer Soiernsee since it is lightflooded down to the bottom for most of the ice-free period. Short-term light-limited conditions exist only during high water levels after snowmelt or after heavy rainfall events with intense surface runoff causing excessive turbidities. Consequently, periphytic diatoms dominate the surface-sediment assemblages, while settled planktonic species occurred infrequently. In contrast, in Lake Oberer Soiernsee light-limiting conditions inhibit periphyton growth in the profundal zone, resulting in high abundances of planktonic diatoms.

Implications for paleolimnological studies

The developed diatom-inferred depth models provide powerful tools to reconstruct water column dynamics (water level, water transparency, thermal stratification) via ratio of benthic/planktonic taxa in Lake Oberer Soiernsee (aphotic conditions) and variations in periphytic diatom assemblages via substrate preferences in Lake Unterer Soiernsee (photic conditions). The spatial variability of the diatom assemblages from near-shore littoral to the deep-water area enables the interpretation of temporal assemblage shifts in sedimentary records (Rühland et al. 2015). If aphotic conditions prevail, diatom assemblages preserved in surface sediment samples comprise a mixture of the lakes diatom communities adapted to different habitats (littoral, pelagial), on distinct substrates (stones, plants, sediment) and in varied environmental conditions (disturbance regime, nutrient concentrations) (Pla-Rabés and Catalan 2018). Hence, in line with our hypothesis 3 , lake level changes will be reflected in the ratio of benthic to planktonic species (B/P ratios) in down-core sediment samples of Lake Oberer Soiernsee, especially when the cores are taken near the littoral/pelagic transition zone. Despite similar biomass of planktonic diatoms in both studied lakes, we found that periphytic diatoms outnumber small-celled Centrales by far in the shallow, well-illuminated Lake Unterer Soiernsee. Consequently, we predict shifts in $\mathrm{B} / \mathrm{P}$ ratios will not be documented in sedimentary records of this lake. Water-level alterations should be recorded via variations within the benthic diatom assemblages. However, interpretation of $\mathrm{B} / \mathrm{P}$ ratio variations is very complex, as primarily changes in the lakes light regimes affect the ratio and lake transparency is influenced by nutrient enrichment (Hall and Smol 1999) as well as by higher erosion rates in the catchment. $\mathrm{B} / \mathrm{P}$ ratios were also used to indicate climate warming. In deep lakes with an extended aphotic zone, stronger stratification patterns result in compositional shift of diatom assemblages from small benthic fragilarioid/heavy silicified tychoplanktonic taxa to small-celled cyclotelloid/elongate pennate planktonic taxa, while in shallow lakes climate warming forces more complex and diverse benthic communities associated with habitat expansion and substrate development, e.g. aquatic vegetation (Rühland et al. 2015).

As we hypothesized (4), the aphotic zone sample of Lake Oberer Soiernsee was appropriate for reconstruction of trophic status. The oligo- to mesotrophic state calculated by indicator species complies with the perennial average of the water column phosphorus concentrations. We choose the trophic index by Hofmann (1999), developed for lakes in southern Germany (inclusive lakes of the Alps) to calculate diatom-related trophic states along the depth gradient. We concede the error susceptibility of this approach, as it relies on ecological preferences of single, partially rare indicator species. In contrast, the basis of a diatom-TP transfer function is the relation of 
whole contemporary diatom assemblage with corresponding TP concentrations (Juggins et al. 2013). The purpose of our linear-relationship method was providing a rough guide to evaluate the size of variance between the single sites and figure out the conformity with water column TP concentrations. Especially in Lake Unterer Soiernsee the calculated trophic indices are highly inconsistent and mainly mirror single point sources: underwater inflows indicated by high abundances of eutraphent Simonsenia delognei, a typical spring water species (Witkowski et al. 2014) lead to meso- to eutrophic conditions as consequence of weathering and erosion of phosphate-containing limestone (Valeton 1988). In contrast, the calculated indices of Lake Oberer Soiernsee were more constant. The higher indices on the northern slope probably reflect pollution by the small mountain hut.

Under aphotic conditions, a surface sediment sample from the deepest part of the basin represents an accumulation of diatom deposits from a variety of in-lake habitats and substrates (Hall and Smol 1999), including planktonic diatoms, which have closer relationship to water column nutrients than benthic diatoms (Althouse et al. 2014). The lack of phytoplanktonic taxa in the sediment constitutes a major problem of surface sediment training sets, as many periphytic diatoms are relatively insensitive to changes in epilimnetic nutrient concentrations (Sayer 2001). Especially epipsammic/epipelic diatom communities, deriving the nutrients from the sediment as well as from the overlying water, would be less suitable to indicate an increase in phosphorus inputs (Bennion et al. 2010). However, epipelic taxa are particularly abundant in the deepest sample of Lake Unterer Soiernsee as a result of absence of stony substrate. Besides that, the in situ benthic communities overprint the accumulation of planktonic and tychoplanktonic taxa in the diatom assemblages of the surface sediments.

Philibert and Prairie (2002) suggested the inclusion of both benthic and planktonic species as a requirement to obtain the most reliable transfer function. However, developing a training set for shallow polymictic lakes, Werner and Smol (2005) found that distribution of benthic diatoms even of small fragilarioid taxa changes significantly with changing epilimnic TP concentrations. In order to develop a diatom-based TP transfer function for Bavarian mountain lakes, it is highly important to consider lake depth and transparency. Our findings highlighted the usefulness of creating two different training sets, one for deep or low-transparency lakes with an aphotic zone including benthic and planktonic diatoms, and another one for shallow, clear water lakes solely based on benthic diatoms. Hence, our results are in line with Werner and Smol (2005) who also recommend separating shallow from deep lakes in their calibration set of Canadian alkaline lakes.

Acknowledgements Open Access funding provided by Projekt DEAL. The study was founded by the Bavarian State Ministry of the Environment and Consumer Protection (Grant Number TKP01KPB-70807). We are grateful to Tanja Gschlöß1 for her appreciative feedback and to Markus Heinrichs for helpful comments on the manuscript. Special thanks are due to Stefanie Rüegg, Severin Sebald and Karin Kronseder for scientific diving and classifying macrophytes. We thank Stefan Ossyssek, Joachim Hilber, Christina Aulehner, Pierre Manthe and Julia Mayr for assistance in field and laboratory. We are thankful to Petra Werner, Marco Cantonati and Horst LangeBertalot for help identifying single diatom taxa. Finally we thank Thomas J. Whitmore, Melanie Riedinger Whitmore, Mark Brenner and another anonymous reviewer for their effort and helpful comments.

Open Access This article is licensed under a Creative Commons Attribution 4.0 International License, which permits use, sharing, adaptation, distribution and reproduction in any medium or format, as long as you give appropriate credit to the original author(s) and the source, provide a link to the Creative Commons licence, and indicate if changes were made. The images or other third party material in this article are included in the article's Creative Commons licence, unless indicated otherwise in a credit line to the material. If material is not included in the article's Creative Commons licence and your intended use is not permitted by statutory regulation or exceeds the permitted use, you will need to obtain permission directly from the copyright holder. To view a copy of this licence, visit http://creativecommons.org/licenses/by/4.0/.

\section{References}

Althouse B, Higgins S, Zanden MJV (2014) Benthic and planktonic primary production along a nutrient gradient in Green Bay, Lake Michigan, USA. Freshw Sci 33(2):487-498

Anderson NJ, Foy RH, Engstrom DR, Rippey B, Alamgir F (2012) Climate forcing of diatom productivity in a lowland, eutrophic lake: white lough revisited. Freshw Biol 57:2030-2043

Battarbee RW, Jones VJ, Flower RJ, Cameron NG, Bennion H, Carvalho L, Juggins S (2001) Diatoms. In: Smol JP, Birks HJB, Last WM (eds) Tracking environmental change using 
lake sediments, vol 3. Terrestrial, algal and siliceous indicators. Kluwer, The Netherlands, pp 155-202

Battarbee RW, Charles DF, Bigler C, Cumming BF, Renberg I (2010) Diatoms as indicators of lake-water acidity. In: Smol JP, Stoermer EF (eds) The diatoms: applications for the environmental and earth sciences. Cambridge University Press, Cambridge, pp 98-121

Becker R, Blindow I, Doege A, Franke T, Gregor T, Hamann U, Jäger D, Jorda C, Kabus T, Korsch H, Korte E, Kusber W-H, Pätzold F, Raabe U, Schubert H, Teppke M, van de Weyer K, Wolff P (2016) Beschreibung der CharaceeaArten Deutschlands. In: Arbeitsgruppe Characeen Deutschlands (eds) Armleuchteralgen Die Characeen Deutschlands. Springer, Berlin

Bennion H, Sayer C, Tibby T, Carrick H (2010) Diatoms as indicators of environmental change in shallow lakes. In: Smol JP, Stoermer EF (eds) The diatoms: Applications for the environmental and earth sciences. Cambridge University Press, Cambridge, pp 152-173

Burkholder JM (1996) Interactions of benthic algae with their substrata. In: Stevenson RJ, Bothwell ML, Lowe RL (eds) Algal ecology, freshwater benthic ecosystems. Academic Press San Diego, California, pp 253-297

Cantonati M, Lowe RL (2014) Lake benthic algae: toward an understanding of their ecology. Freshw Sci 33(2):475-486

Cantonati M, Scola S, Angeli N, Guella G, Frassanito R (2009) Environmental controls of epilithic diatom depth-distribution in an oligotrophic lake characterized by marked water-level fluctuations. Eur J Phycol 44(1):15-29

Catalan J, Pla-Rabés S, Wolfe AP, Smol JP, Rühland KM, Anderson NJ, Kopácek J, Stuchlík E, Schmidt R, Koinig KA, Camarero L, Flower R, Heiri O, Kamenik C, Korhola A, Laevitt PR, Psenner R, Renberg I (2013) Global change revealed by palaeolimnological records from remote lakes: a review. J Paleolimnol 49:513-535

Clarke KR (1993) Non-parametric multivariate analyses of changes in community structure. Aust J Ecol 18:117-143

DIN EN 15204:2006: European Standard Water quality. Guidance standard on the enumeration of phytoplankton using inverted microscopy (Utermoehl technique)

DIN EN 16698:2015-12: European Standard Water Quality. Guidance on quantitative and qualitative sampling of phytoplankton from inland waters

DIN EN ISO 6878:2004-09: European Standard (2004) Water Quality. Determination of phosphorus- Ammoniummolybdate spectrometric method

DIN 38405-9:2011-09 German Standard methods for examination of water, waste water and sluge-anions (Group D)Part 9. Spectrometric determination of nitrate (D9)

Dodds WK (2003) The role of periphyton in phosphorus retention in shallow freshwater aquatic systems. J Phycol 39:840-849

Dokulil MT (2013) Impact of climate warming on European inland waters. Inland Waters 4:27-40

Feret LE, Bouchez A, Rimet F (2017) Benthic diatom communities in high altitude lakes: a large scale study in the French Alps. Ann Limnol Int J Limnol 53:411-423

Forehead HI, Thompson PA (2010) Microbial communities of subtidal shallow sandy sediments change with depth and wave disturbance, but nutrient exchanges remain similar. Mar Ecol Prog Ser 414:11-26
Guiry MD, Guiry GM (2019) AlgaeBase. World-wide electronic publication, National University of Ireland, Galway. http://www.algaebase.org

Gushulak CAC, Laird KR, Bennett JR, Cumming BF (2017) Water depth is a strong driver of intra-lake diatom distributions in a small boreal lake. J Paleolimnol 58:231-241

Hall RI, Smol JP (1999) Diatoms as indicators of lake eutrophication. In: Stoermer EF, Smol JP (eds) The diatoms: applications for the environmental and earth sciences. Cambridge University Press, Cambridge, pp 128-168

Hammer , Harper DAT (2006) Paleontological data analysis. Blackwell, Malden

Hill WR (1996) Effects of light. In: Stevenson RJ, Bothwell ML, Lowe RL (eds) Algal ecology, freshwater benthic ecosystems. Academic Press, San Diego, pp 121-148

Hofmann G (1999) Trophiebewertung von Seen anhand von Aufwuchsditomeen. In: von Tümpling W, Friedrich $G$ (eds) Biologische Gewässeruntersuchung. Gustav Fischer Verlag, Jena, pp 319-333

Hofmann H, Lorke A, Peeters F (2008) Temporal scales of water-level fluctuations in lakes and their ecological implications. Hydrobiologia 613:85-96

Hofmann G, Werum M, Lange-Bertalot H (2013) Diatomeen im Süßwasser-Benthos von Mitteleuropa, 2nd edn. Koeltz Scientific Books, Königstein

Jacobson PC, Hansen GJA, Bethke BJ, Cross TK (2017) Disentangling the effects of a century of eutrophication and climate warming on freshwater lake fish assemblages. PLoS ONE 12(8):e0182667

Jeppesen E, Moss B, Bennion H, Carvalho L, De Meester L, Feuchtmayr H, Friberg N, Gessner MO, Hefting M, Lauridsen TL, Liboriussen L, Malmquist HJ, May L, Meerhoff M, Olafsson JS, Soons MB, Verhoeven JTA (2010) Interaction of climate change and eutrophication. In: Kernan M, Battarbee RW, Moss B (eds) Climate change impacts on freshwater ecosystems. Wiley-Blackwell, Chichester, pp 119-151

Juggins S (2018) Package 'rioja'. CRAN R-Project, p 58

Juggins S, Anderson NJ, Hobbs JMR, Heathcote AJ (2013) Reconstructing epilimnetic total phosphorus using diatoms: statistical and ecological constraints. J Paleolimnol 49:373-390

Kamenik C, Koinig KA, Schmidt R, Appleby P, Dearing J, Lami A, Thompson R, Psenner R (2000) Eight hundred years of environmental changes in a high alpine lake (Gossenköllesee, Tyrol) inferred from sediment records. J Limnol 59:43-52

Kingsbury MV, Laird KR, Cumming BF (2012) Consistent patterns in diatom assemblages and diversity measures across water-depth gradients from eight Boreal lakes from North-Western Ontario (Canada). Freshw Biol 57:1151-1165

Kitner M, Poulíčková A (2003) Littoral diatoms as indicators for the eutrophication of shallow lakes. Hydrobiologia 506:519-524

Krammer K (1997) Die cymbelloiden Diatomeen. Eine Monographie der weltweit bekannten Taxa, 1-2. Bibliotheca Diatomologica. Cramer, Berlin

Krammer K, Lange-Bertalot H (1986-1991) Bacillariophyciae 1-4. In: Ettl H, Gerloff J, Heynig H, Mollenhauer D (eds) 
Süßwasserflora von Mitteleuropa. Gustav Fischer Verlag, Stuttgart

Laird KR, Kingsbury MV, Cumming BF (2010) Diatom habitats, species diversity and water-depth inference models across surface-sediment transects in Worth Lake, northwest Ontario, Canada. J Paleolimnol 44:1009-1024

Lange-Bertalot H, Krammer K (2000-2003) Diatoms of Europe vol. 1-4, A.R.G. Ganter Verlag K.G., Rugell

Legendre P, Gallagher ED (2001) Ecologically meaningful transformations for ordination of species data. Oecologia 129:271-280

Leira M, Filippi ML, Cantonati M (2015) Diatom community response to extreme water-level fluctuations in two Alpine lakes: a core case study. J Paleolimnol 53:289-307

Lepš J, Šmilauer P (2003) Multivariate analysis of ecological data using CANOCO. Cambridge University Press, Cambridge

Letáková M, Cantonati M, Hašler P, Angeli N, Poulíčková A (2016) Substrate specificity and fine-scale distribution of epiphytic diatoms in a shallow tarn in the Brenta Dolomites (south-eastern Alps). Plant Ecol Evol 149(2):144-156

Lewin JC (1953) Heterotrophy in diatoms. J General Microbiol 9(2):305-313

Lowe RL (1996) Periphyton patterns in lakes. In: Stevenson RJ, Bothwell ML, Lowe RL (eds) Algal ecology, freshwater benthic ecosystems. Academic Press, San Diego, pp 57-76

März C (1903) Der Seenkessel der Soiern - Ein Karwendelkar. Duncker und Humblot, Leipzig

Messyasz B, Kuczyńska-Kippen N (2006) Periphytic algal communities: a comparison of Typha angustifolia L. and Chara tomentosa L. beds in three shallow lakes (West Poland). Pol J Ecol 54(1):15-27

Moos MT, Laird KR, Cumming BF (2005) Diatom assemblages and water depth in Lake 239 (Experimental Lakes Area, Ontario): implications for paleoclimatic studies. J Paleolimnol 34:217-227

Moss B (1977) Adaptations of epipelic and epipsammic freshwater algae. Oecologia 28:103-108

Navone R (1964) Proposed method for nitrate in potable waters. J Am Water Works Assoc 56:781-783

Novais MH, Morais MM, Rosado J, Dias LS, Hoffmann L, Ector L (2014) Diatoms of temporary and permanent watercourses in Southern Europe (Portugal). River Res Appl 30:1216-1232

Oksanen J, Blanchet FG, Friendly M, Kindt R, Lengendre P, McGlinn D, Minchin PR, O'Hara RB, Simpson GL, Solymos P, Stevens MHH, Szoecs E, Wagner H (2018) Package 'vegan'. CRAN R-Project, 1-297

Passy SI (2007) Diatom ecological guilds display distinct and predictable behavior along nutrient and disturbance gradients in running waters. Aquat Bot 86:171-178

Perga ME, Frossard V, Jenny JP, Alric B, Arnaud F, Berthon V, Black J, Domaizon I et al (2015) High-resolution paleolimnology opens new management perspectives for lakes adaptation to climate warming. Front Ecol Evol 3:72

Philibert A, Prairie YT (2002) Is the introduction of benthic species necessary for open-water chemical reconstruction in diatom-based transfer functions? Can J Fish Aquat Sci 59:938-951
Pla-Rabés S, Catalan J (2018) Diatom species variation between lake habitats: implications for interpretation of paleolimnological records. J Paleolimnol 60(2):169-187

Poulíčková A, Hašler P (2007) Aerophytic diatoms from caves in central Moravia (Czech Republic). Preslia 79:185-204

Poulíčková A, Hašler P, Lysáková M, Spears B (2008) The ecology of freshwater epipelic algae: an update. Phycologia 47(5):437-450

Raposeiro PM, Saez A, Giralt S, Costa AC, Gonçalves V (2018) Causes of spatial distribution of subfossil diatom and chironomid assemblages in surface sediments of a remote deep island lake. Hydrobiologia 815:141-163

Rørslett B (1991) Principal determinants of aquatic macrophyte richness in northern European lakes. Aquat Bot 39:173-193

Round FE, Crawford RM, Mann DG (1990) The diatoms, biology and morphology of the genera. Cambridge University Press, Cambridge

Rühland K, Smol JP (2005) Diatom shifts as evidence for recent Subarctic warming in a remote tundra lake, NWT, Canada. Palaeogeogr Palaeoclimatol Palaeoecol 226:1-16

Rühland KM, Paterson AM, Smol JP (2015) Lake diatom responses to warming: reviewing the evidence. $\mathrm{J}$ Paleolimnol 54:1-35

Sayer CD (2001) Problems with the application of diatom- total phosphorus transfer functions: examples from a shallow English lake. Freshw Biol 46:743-757

Sayer CD, Roberts N (2001) Establishing realistic restoration targets for nutrient-enriched shallow lakes: linking diatom ecology and palaeoecology at the Attenborough Ponds, UK. Hydrobiologia 448:117-142

Schaumburg J, Schranz C, Stelzer D, Vogel A (2014) Verfahrensanleitung für die ökologische Bewertung von Seen zur Umsetzung der EG-Wasserrahmenrichtlinie: Makrophyten and Phytobenthos. Bayerisches Landesamt für Umwelt, München

Schmidt-Thome P (1953) Beobachtungen an Karen im Vorkarwendel. Geologica Bavarica. Bayerisches Geologisches Landesamt, München

Smol JP (2008) Pollution of Lakes and Rivers: a paleoenvironmental perspective, 2nd edn. Blackwell Publishing, Oxford

Spaudling SA, Bishop IW, Edlund MB, Potapova M (2018) Diatoms of North America. https://diatoms.org/

Stevenson RJ, Stoermer EF (1981) Quantitative differences between benthic algal communities along a depth gradient in Lake Michigan. J Phycol 17:29-36

Tilzer MM (1988) Secchi disk-chlorophyll relationships in a lake with highly variable phytoplankton biomass. Hydrobiologia 162:163-171

Tuchman NC, Schollett MA, Rier ST, Geddes P (2006) Differential heterotrophic utilization of organic compounds by diatoms and bacteria under light and dark conditions. Hydrobiologia 561:167-177

Vadeboncoeur Y, Devlin S, McIntyre PB, Zanden MJV (2014) Is there light after depth? Distribution of periphyton chlorophyll and productivity in lake littoral zones. Freshw Sci 33(2):524-536

Valeton I (1988) Sedimentäre Phosphatgesteine. In: Füchtbauer N (ed) Sedimente und Sedimentgesteine. E. Schweizbart, Stuttgart, pp 543-567 
van Dam H, Mertens A, Sinkeldam J (1994) A coded checklist and ecological indicator values of freshwater diatoms from the Netherlands. Neth J Aquat Ecol 28:117-133

Werner P, Smol JP (2005) Diatom-environmental relationships and nutrient transfer functions from contrasting shallow and deep limestone lakes in Ontario, Canada. Hydrobiologica 533:145-173

Wetzel RG (2001) Limnology Lake and River. Academic Press, San Diego

Witkowski A, Żelazna-Wieczorek J, Solak CN, Kulikovskiy M (2014) Morphology, ecology and distribution of the diatom (Bacillariophyceae) species Simonsenia delognei (Grunow) Lange-Bertalot. Ocean Hydrol 43(4):393-401
Wolfe AP, Baron JS, Cornett RJ (2001) Anthropogenic nitrogen deposition induces rapid ecological changes in alpine lakes of the Colorado Front Range (USA). J Paleolimnol 25:1-7

Yang H, Flower RJ (2012) Effects of light and substrate on the benthic diatoms in an oligotrophic lake: a comparison between natural and artificial substrates. J Phycol 48:1166-1177

Publisher's Note Springer Nature remains neutral with regard to jurisdictional claims in published maps and institutional affiliations. 